\title{
Increased healthy osteoblast to osteosarcoma density ratios on specific PLGA nanopatterns
}

\author{
This article was published in the following Dove Press journal: \\ International Journal of Nanomedicine \\ 4 January 2013 \\ Number of times this article has been viewed
}

\author{
Yongchen Wang' \\ Lijuan Zhang' \\ Linlin Sun ${ }^{2}$ \\ Thomas J Webster ${ }^{2,3}$ \\ 'Department of Chemistry, ${ }^{2}$ School \\ of Engineering, ${ }^{3}$ Department of \\ Orthopedics, Brown University, \\ Providence, RI, USA
}

\begin{abstract}
Poly(lactic-co-glycolic acid) ([PLGA] 50:50 wt\% PLA:PGA) films with a flat surface and with $27 \mathrm{~nm}, 190 \mathrm{~nm}, 300 \mathrm{~nm}, 400 \mathrm{~nm}$, and $520 \mathrm{~nm}$ nanopatterns were fabricated using a cast-mold process. The nanopatterns were transferred from self-assembled polystyrene (PS) beads to PLGA films through polydimethylsiloxane (PDMS) molds. The surface features, rootmean-square (RMS) roughness, and wettability of these PLGA surface features were studied by atomic force microscope (AFM) height scans, AFM z-sensor scans, and water contact angles, respectively. In order to evaluate the influence of the material topography alone (without changes in chemistry) for bone-cancer applications, both human healthy osteoblasts and human cancerous osteosarcoma cells were cultured on these PLGA surface features, and their densities were determined. Most importantly, compared to all other substrates, it was found that the $27 \mathrm{~nm}$ PLGA nanopatterns significantly increased the healthy osteoblast-to-osteosarcoma cell-density ratio. For these reasons, and since previous studies have highlighted that similar nanometer PLGA surface features decreased functions of other types of cancerous cells (specifically lung and breast), this study suggests that $27 \mathrm{~nm}$ PLGA nanopatterns should be further studied for a wide range of bone-cancer applications, particularly where healthy bone-cell functions need to be promoted over cancerous bone-cell functions.
\end{abstract}

Keywords: polymers, cancer, anti-cancer, surface nanometer features, bone, surface wettability

\section{Introduction}

In recent years, there have been a number of studies carried out to determine ways to manipulate cellular functions. ${ }^{1-3}$ In particular, substrate micro- and nanotopographies have been shown to provide critical cues for cells, influencing cell morphology and a series of other cell functions, including adhesion, migration, proliferation, differentiation, apoptosis, and so on. ${ }^{1,4-33}$ Studies focusing on bone cells and their cellular responses to nanotopographies have been widely conducted. For example, nanophase ceramics, titanium/Poly (lactic-co-glycolic acid) (PLGA) nanocomposites, nanoporous alumina, and nanophase metals have all been shown to increase bone growth. ${ }^{5-8}$ This phenomenon was mainly explained in that these nanotopographies mimic the natural nanofeatures of the bone extracellular matrix ([ECM] measured at a $78 \mathrm{~nm}$ root mean square roughness in a $5 \times 5$-micron atomic force microscope [AFM] scan $^{10}$ ), which consists of interstitial matrices and basement membranes, presenting numerous nanoscale topographies and structures to cells. ${ }^{9}$ It has been demonstrated that these nanoscale features alter substrate surface energy to influence the adsorption of endogenous proteins, which dictates cellular functions, and thus regulates cell behavior. ${ }^{5}$
Correspondence: Thomas J Webster Department of Chemical Engineering, 360 Huntington Avenue, 3I3A Snell Engineering Center, Northeastern University, Boston, MA 02115, USA $\mathrm{Tel}+\mathrm{I} 6173736585$

Fax +I 6173732209

Email th.webster@neu.edu 
However, up until now, research on the interactions between cells and nanotopographies has mainly focused on healthy mammalian cells with less (if any) attention paid toward controlling cancer-cell functions. Of the few studies conducted on bone-cancer cells, nanoscale calcium phosphate particles were found to cause size-dependent suppression of osteosarcoma cell proliferation, inducing cell apoptosis due to changes in surface energetics. ${ }^{34,35}$ However, in such studies, the fundamental material properties (such as chemistry, crystallinity, and energy) responsible for such events remain unclear.

There is also much promise for the use of PLGA in orthopedic applications. First, PLGA has been widely studied in tissue engineering as a whole, in drug delivery systems, and in anticancer research because of its well-known tailorable biocompatibility and biodegradability properties. Second, previous work demonstrated that PLGA films with select nanopatterns inhibited functions of lung cancerous cells and breast cancerous cells while promoting respective healthy cell functions. ${ }^{36-38}$ For example, compared to nanosmooth PLGA, for lung and breast cancerous cells, PLGA films with $23 \mathrm{~nm}$ surface features inhibited synthesis of vascular endothelial cell growth factor (VEGF), which increases tumor angiogenesis, allowing for metastasis. ${ }^{36-38}$

In this work, cellular responses of human healthy osteoblasts and human cancerous osteosarcoma cells to different PLGA nanometer surface features were studied and compared for the first time. Due to the cast-mold process employed here, the chemistry of the various PLGA samples was the same; thus, the effects of the nanotopographies alone on osteoblast and osteosarcoma cell behavior could be isolated. For all of the above reasons, this study hypothesized that nanoscale surface features on polymers could increase healthy osteoblast over cancerous osteoblast density. Thus, the goal of this study was to determine if PLGA nanofeatures alone (and without the use of chemotherapeutic agents) could selectively decrease osteosarcoma responses while promoting healthy osteoblast responses - important criteria for numerous orthopedic applications, including generating new healthy bone after cancerous bone tumors have been removed.

\section{Methods Materials}

PLGA nanopatterns of different sizes were fabricated using a cast-mold process (Figure 1). Nanopatterns were initially created by the self-assembly process of various polystyrene beads (Bangs Laboratories, Inc, Fishers, IN) of a series of sizes, including $27 \mathrm{~nm}, 190 \mathrm{~nm}, 300 \mathrm{~nm}, 400 \mathrm{~nm}$, and $520 \mathrm{~nm}$ diameters placed on $18 \mathrm{~mm}$ glass coverslips (Thermo Fisher Scientific, Waltham, MA). The $18 \mathrm{~mm}$ glass coverslips were immersed in acetone for 10 minutes, sonicated in acetone for 10 minutes, washed with distilled (DI) water several times, immersed in ethanol for 10 minutes, sonicated in ethanol for 10 minutes, and washed with DI water several times in sequential order. After the coverslips were dry, 150 microliters of $27 \mathrm{~nm}$ polystyrene beads, 300 microliters of $190 \mathrm{~nm}$ polystyrene beads, 300 microliters of $300 \mathrm{~nm}$

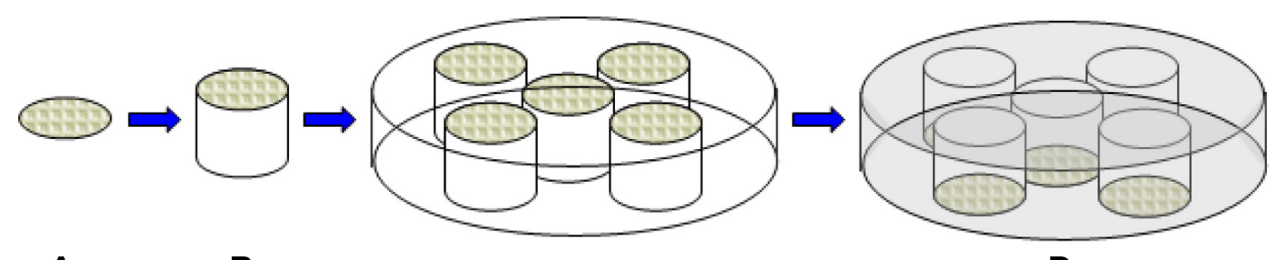

A

B

C

D

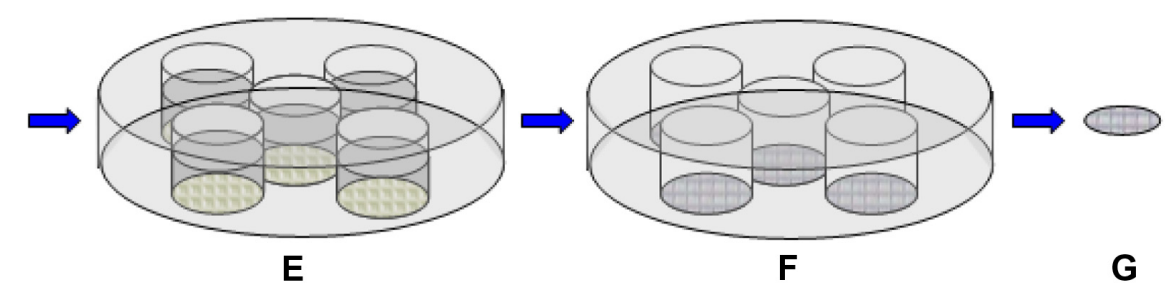

Figure I The process of transferring nanopatterns from polystyrene beads to PLGA films through the use of PDMS molds. (A) Self-assembly of polystyrene beads with diameters of $27 \mathrm{~nm}, 190 \mathrm{~nm}, 300 \mathrm{~nm}, 400 \mathrm{~nm}$, and $520 \mathrm{~nm}$ on the $18 \mathrm{~mm}$ coverslips. (B) Assembling the coverslips with the polystyrene beads on the top side of the glass columns. (C) Assembling the glass columns onto the bottom of petri dishes. (D) The PDMS molds with a nanofeatured surface on the bottom of each well. (E) A PLGA solution was added at a ratio of I mL into each well of the PDMS molds. (F) Chloroform vaporized and PLGA nanopatterns of $27 \mathrm{~nm}, 190 \mathrm{~nm}, 300 \mathrm{~nm}, 400 \mathrm{~nm}$, and $520 \mathrm{~nm}$ were fabricated. (G) Assembling PLGA films on 12 mm coverslips.

Notes: The gray color represents the surface with nanopatterns. Controls consisted of PLGA created without the use of any beads (ie, flat). Abbreviations: PDMS, polydimethylsiloxane; PLGA, poly(lactic-co-glycolic acid). 
polystyrene beads, 300 microliters of $400 \mathrm{~nm}$ polystyrene beads, and 300 microliters of $520 \mathrm{~nm}$ polystyrene beads were pipetted onto the top of each pretreated coverslip separately. In accordance with prior experimental evidence, different volumes of beads were used in order to create as much of a monolayer of beads on the glass surface as possible. The self-assembly of the negatively charged polystyrene beads occurred for 24 hours while the solvent evaporated in air at room temperature, creating the initial nanopatterns.

Then, the coverslips with polystyrene beads were assembled on the top side of the glass columns, of which the diameter of the underside was customized to $18 \mathrm{~mm}$, and the bottoms of the glass columns were assembled onto the petri dishes with a commercialized glue (Caliber, New York, NY). Next, $100 \mathrm{~mL}$ of a mixture of polydimethylsiloxane ([PDMS] Dow Corning Corporation, Midland, MI), prepared according to manufacturer's instructions, was poured into the petri dishes, and the polymerization took place in contact with the self-assembled polystyrene beads for 48 hours. This was done in order to transfer the nanopatterns from the polystyrene beads to the PDMS molds. The PDMS molds with a flat surface were also synthesized as a control group by using smooth pretreated coverslips without polystyrene beads. All PDMS molds with nanopatterns were washed with chloroform five times for 5 minutes each time to remove polystyrene bead residuals. After that, the PDMS molds were placed into the lids of petri dishes with $15 \mathrm{~mL}$ of a mixture of PDMS at a ratio of 10:1 for another 48 hours. Then, PDMS molds were stabilized by a PDMS base in order to minimize the deformation of the molds induced by the chloroform used later.

Next, PLGA (50:50 wt\% PLA:PGA; molecular weight: 150,000) (Polysciences, Inc, Warrington, PA) was dissolved in chloroform at a ratio of $0.5 \mathrm{~g}$ PLGA $/ 8 \mathrm{~mL}$ chloroform for 1 hour and ultrasonicated for 10 minutes. Afterward, $1 \mathrm{~mL}$ of this PLGA solution was added to the PDMS molds for each sample. After 48 hours, the chloroform evaporated, and PLGA films with nanopatterns of various sizes on the surface were synthesized by replicating the nanopatterns from the PDMS molds onto the PLGA film surfaces. Finally, the PLGA films were assembled on the $12 \mathrm{~mm}$ coverslips (Thermo Fisher Scientific), with the nanopatterns facing up for further characterization and cell studies.

\section{Material characterization}

The surface features of the PLGA films were studied using an MFP-3DTM Stand Alone AFM (Asylum Research, Goleta, CA). AFM contact mode was selected with a sharp-tipped AFM cantilever with a K-value of $0.06 \mathrm{~N} / \mathrm{m}$; the scanning size used was $5 \mu \mathrm{m} \times 5 \mu \mathrm{m}$. The root-meansquare (RMS) roughness values and surface area of PLGA nanopatterns were calculated from the flattened AFM z-sensor scan images by the AFM analysis software Igor Pro (v 1; WaveMetrics, Inc, Lake Oswego, OR). The wettability of PLGA nanopatterns was evaluated by measuring the water contact angles of the PLGA films with a DSA10 contactangle goniometer (KRÜSS GmbH, Hamburg, Germany). EasyDrop software (v 1; EasyDrop, Minneapolis, MN) was used to operate the measurements and record the data. Three microliters of $\mathrm{H}_{2} \mathrm{O}$ was dropped on the sample surface at a rate of $100 \mu \mathrm{L} /$ minute and the contact angle was measured every second in the following 60 seconds. The average value of contact angle was calculated from nine samples for each surface feature.

\section{Cell studies}

Human healthy osteoblasts (CRL-11372; American Type Culture Collection [ATCC], Manassas, VA; established by transfection of limb tissue) were cultured in Dulbecco's modified Eagle's medium (DMEM) containing 1\% penicillin/ streptomycin $(\mathrm{P} / \mathrm{S})$ and $10 \%$ fetal bovine serum (FBS). Human cancerous osteosarcoma cells (CRL-1427; ATCC; MG-63 isolated from bone cancer from a 14-year-old male) were cultured in Eagle's minimum essential medium (EMEM) containing 1\% P/S and 10\% FBS. All cells were cultured in cell-culturing flasks (Corning Incorporated, Corning, NY) under a humidified $37^{\circ} \mathrm{C} 5 \% \mathrm{CO}_{2}$ environment.

Four-hour cell adhesion assays (seeding cell density: 3500 cells $\left./ \mathrm{cm}^{2}\right)$ were assessed by 3-(4,5-Dimethylthiazol2-yl)-2,5-diphenyltetrazolium bromide (MTT) assays to evaluate osteoblast and osteosarcoma cell density on the various PLGA surface features. Three samples were prepared for each surface feature. The PLGA films were pretreated with $70 \%$ ethanol for sterilization for 20 minutes and washed with phosphate-buffered saline (PBS) three times. Then, three samples were placed into 24-well plates (Corning Incorporated). Both osteoblasts and osteosarcoma cell suspensions $\left(3500 \mathrm{cells} / \mathrm{cm}^{2}\right)$ in their respective growth mediums were added $(1 \mathrm{~mL})$ to each sample. The cells were cultured on the PLGA films in an incubator with the aforementioned standard culturing environment for 4 hours. After 4 hours, the samples were transferred into another 24-well plate, and $1 \mathrm{~mL}$ of fresh medium and $150 \mu \mathrm{L}$ of dye solution (Promega Corporation, Fitchburg, WI) were added to each sample. After the samples were kept in the incubator for another 4 hours, $1 \mathrm{~mL}$ of a solubilization/stop solution (Promega Corporation) per 
sample was added. Overnight, the solution over each sample was transferred into a 96-well plate (Corning Incorporated) at a ratio of $200 \mu \mathrm{L}$ per well, and the absorbance of the solution was read by a SpectraMax 340PC384 Absorbance Microplate Reader (Molecular Devices LLC, Sunnyvale, CA) under a wavelength of $570 \mathrm{~nm}$, and the absorbance was converted to cell density according to a standard curve. For the creation of a standard curve, cell numbers were counted with a hemocytometer.

\section{Statistical analysis}

All studies were completed in triplicate and repeated at least three times each. All experimental data were analyzed using a one-tailed Student's $t$-test supplied by a Microsoft Office Excel 2007 (Microsoft Corporation, Redmond, WA); a $P$-value less than 0.05 was regarded as significant.

\section{Results and discussion Surface characterization of PLGA nanopatterns}

AFM images (Figure 2) confirmed that all the expected PLGA surface features, including $27 \mathrm{~nm}, 190 \mathrm{~nm}, 300 \mathrm{~nm}$, $400 \mathrm{~nm}$, and $520 \mathrm{~nm}$ nanopatterns and a flat surface, were created in this study. More importantly, the $27 \mathrm{~nm}$ PLGA nanopatterns exhibited the largest RMS roughness value, and their surfaces were the most hydrophobic (Table 1). The flat PLGA surfaces showed the smallest RMS roughness value, and its surface was the most hydrophilic. Surface area increased by $276 \%, 25 \%, 75 \%, 68 \%$, and $72 \%$, compared to the flat surfaces, for the $27 \mathrm{~nm}, 190 \mathrm{~nm}, 300 \mathrm{~nm}, 400 \mathrm{~nm}$, and $520 \mathrm{~nm}$ nanopatterns, respectively.

\section{Increased healthy osteoblast-to- osteosarcoma cell-density ratio on $27 \mathrm{~nm}$ PLGA surfaces}

Strikingly, results showed that the $27 \mathrm{~nm}$ patterned PLGA had the largest ratio of healthy osteoblast-to-osteosarcoma cell density compared to that of any other material tested (Table 2; Figure 3). Due to the design of this study, it was possible to further conclude that changes in chemistry between the $27 \mathrm{~nm}$ patterned PLGA and other PLGA substrates did not cause this difference. Consequently, to further investigate the material properties responsible for this effect, correlations between osteoblast or osteosarcoma cell density and the material surface properties, including RMS roughness and wettability, were determined. From the correlation
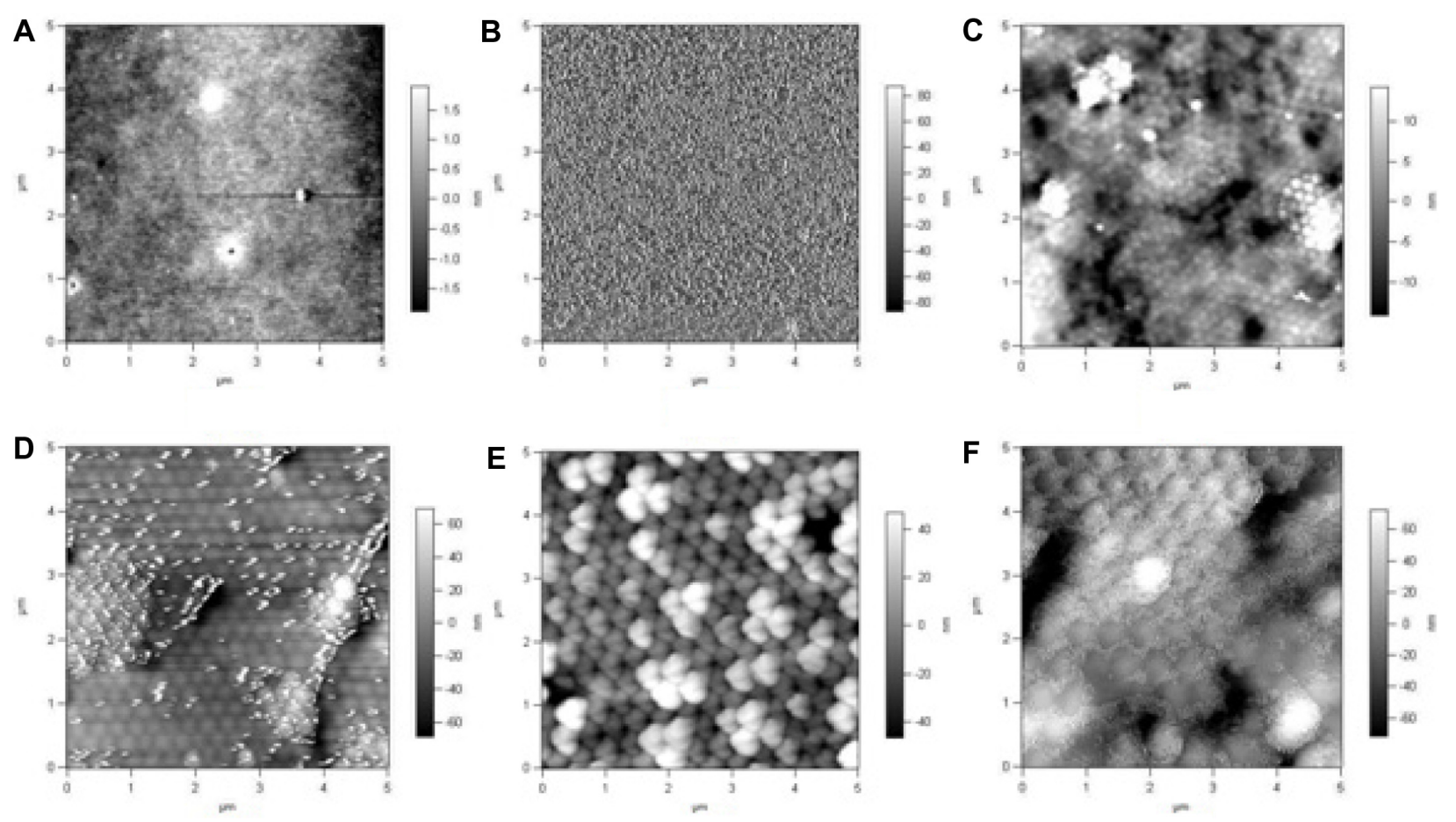

Figure 2 Height scan AFM images of the flat PLGA film and the PLGA films with nanopatterns on the surface. (A) Control (flat) PLGA film. (B) PLGA film with 27 nm nanopatterns on the surface. (C) PLGA film with $190 \mathrm{~nm}$ nanopatterns on the surface. (D) PLGA film with $300 \mathrm{~nm}$ nanopatterns on the surface. (E) PLGA film with $400 \mathrm{~nm}$ nanopatterns on the surface. (F) PLGA film with $520 \mathrm{~nm}$ nanopatterns on the surface (scanning sizes: $5 \mu \mathrm{m} \times 5 \mu \mathrm{m}$ ).

Abbreviations: AFM, atomic force microscope; PLGA, poly(lactic-co-glycolic acid). 
Table I RMS roughness values obtained from AFM and water contact angles on the flat PLGA film and PLGA films with 27 nm nanopatterns, $190 \mathrm{~nm}$ nanopatterns, $300 \mathrm{~nm}$ nanopatterns, $400 \mathrm{~nm}$ nanopatterns, and $520 \mathrm{~nm}$ nanopatterns on the surface

\begin{tabular}{lllllll}
\hline Subgroup & Flat & $\mathbf{2 7} \mathbf{~ n m}$ & $190 \mathbf{n m}$ & $\mathbf{3 0 0} \mathbf{~ n m}$ & $\mathbf{4 0 0} \mathbf{~ n m}$ & $\mathbf{5 2 0} \mathbf{n m}$ \\
\hline RMS & $0.710 \mathrm{~nm}$ & $40.123 \mathrm{~nm}$ & $4.535 \mathrm{~nm}$ & $25.553 \mathrm{~nm}$ & $18.950 \mathrm{~nm}$ & $24.973 \mathrm{~nm}$ \\
Average deviation & $0.539 \mathrm{~nm}$ & $35.068 \mathrm{~nm}$ & $3.492 \mathrm{~nm}$ & $15.379 \mathrm{~nm}$ & $15.607 \mathrm{~nm}$ & $18.436 \mathrm{~nm}$ \\
Average contact & $84.28^{\circ}$ & $97.18^{\circ}$ & $89.56^{\circ}$ & $95.54^{\circ}$ & $91.01^{\circ}$ & $95.47^{\circ}$ \\
$\begin{array}{l}\text { angle } \\
\text { Standard deviation }\end{array}$ & $1.97^{\circ}$ & $1.13^{\circ}$ & $2.21^{\circ}$ & $2.09^{\circ}$ & $2.29^{\circ}$ & $1.99^{\circ}$ \\
\hline
\end{tabular}

Note: Control PLGA consisted of no surface features (flat).

Abbreviations: AFM, atomic force microscopy; PLGA, poly(lactic-co-glycolic acid); RMS, root-mean-square.

Table 2 Ratio of healthy OB density to OS cell density cultured on the same PLGA surface features

\begin{tabular}{lllllll}
\hline Subgroup & Flat & $\mathbf{2 7} \mathbf{n m}$ & $\mathbf{1 9 0} \mathbf{n m}$ & $\mathbf{3 0 0} \mathbf{n m}$ & $\mathbf{4 0 0} \mathbf{n m}$ & $\mathbf{5 2 0} \mathbf{n m}$ \\
\hline $\begin{array}{l}\text { OB cell } \\
\text { density }\end{array}$ & 1237.172 & 2826.876 & 1069.718 & 1549.777 & 1446.091 & 1098.095 \\
$\begin{array}{l}\text { OS cell } \\
\text { density }\end{array}$ & 1180.288 & 1912.053 & 1405.786 & 1195.309 & 1235.786 & 1382.309 \\
\begin{tabular}{l} 
OB/OS ratio \\
\hline
\end{tabular} & 1.048195 & 1.478451 & 0.76094 & 1.296549 & 1.170179 & 0.794392 \\
\hline
\end{tabular}

Note: Control PLGA consisted of no surface features (flat).

Abbreviations: OB, osteoblast; OS, osteosarcoma; PLGA, poly(lactic-co-glycolic acid).

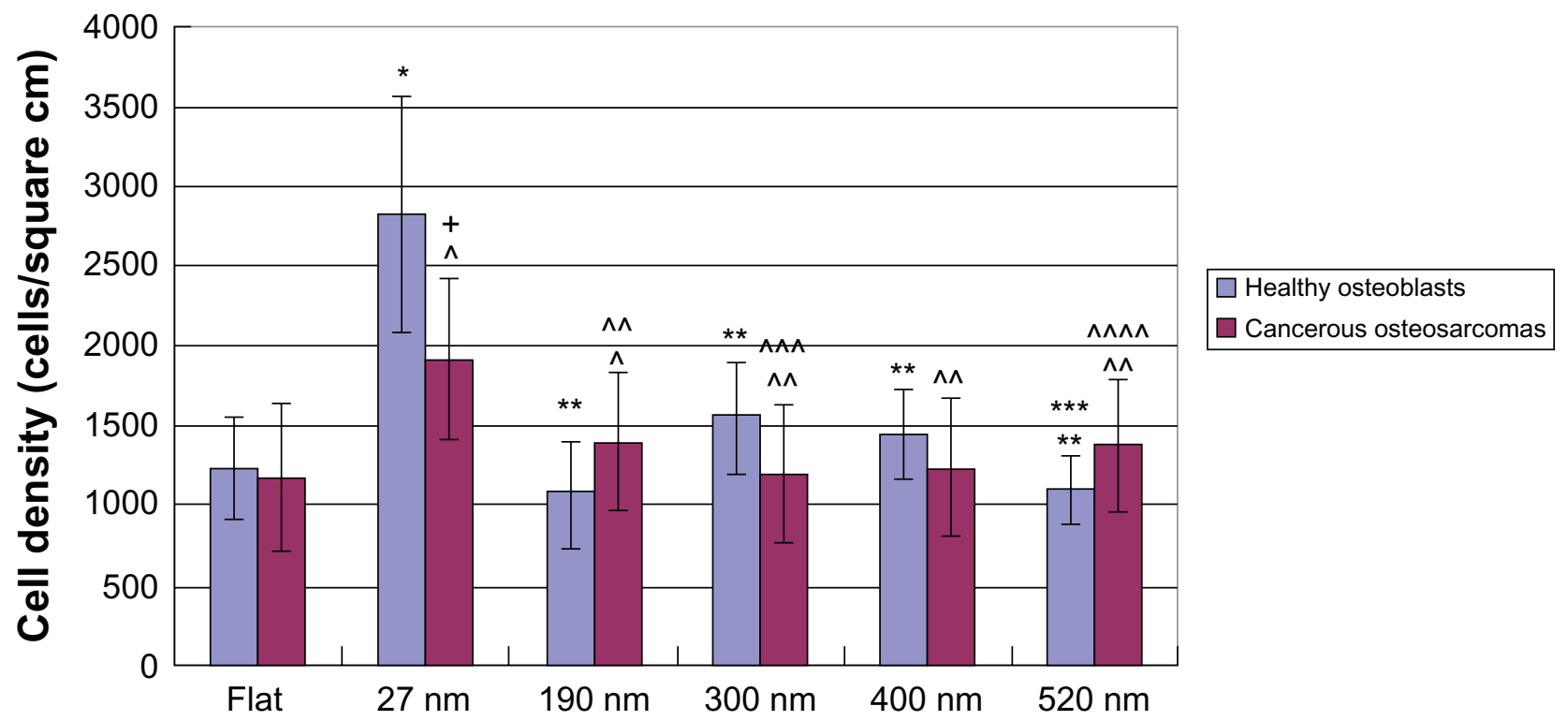

Figure 3 Four-hour cell adhesion results of healthy osteoblasts and osteosarcoma cells $\left(\mathrm{n}=3\right.$; seeding density: $\left.3500 \mathrm{cells} / \mathrm{cm}^{2}\right)$.

Notes: The cell densities are average values \pm SEM. For osteoblasts alone, *, **, and *** represent $P<0.05$ compared with the flat, $27 \mathrm{~nm}$, and $300 \mathrm{~nm}$ surface features, respectively. For osteosarcoma cells alone, $\wedge, \wedge \wedge, \wedge \wedge \wedge$, and $\wedge \wedge \wedge \wedge$ represent $P<0.05$ compared with the flat, $27 \mathrm{~nm}, 190 \mathrm{~nm}$, and $300 \mathrm{~nm}$ surface features, respectively. For osteosarcoma cell density, + represents $P<0.05$ for osteosarcoma cell density compared with healthy osteoblast density on the same surface features. Control PLGA consisted of no surface features (flat).

Abbreviations: PLGA, poly(lactic-co-glycolic acid); SEM, standard error of the mean.

Table $3 R^{2}$-values and $R$-values of the correlation plots of healthy OB density/RMS roughness values obtained from AFM, healthy OB density/contact angle, OS cell density/RMS values obtained from AFM, and OS cell density/contact angle

\begin{tabular}{lllll}
\hline Subgroup & $\begin{array}{l}\text { OB density } \\
\text { and RMS }\end{array}$ & $\begin{array}{l}\text { OB density and } \\
\text { contact angle }\end{array}$ & $\begin{array}{l}\text { OS cell density } \\
\text { and RMS }\end{array}$ & $\begin{array}{l}\text { OS cell density } \\
\text { and contact angle }\end{array}$ \\
\hline $\mathrm{R}^{2}$ values & 0.5882 & 0.2990 & 0.4392 & 0.3117 \\
$\mathrm{R}$ values & 0.7669 & 0.5468 & 0.6627 & 0.5583 \\
\hline
\end{tabular}

Abbreviations: AFM, atomic force microscopy; OB, osteoblast; OS, osteosarcoma cell; RMS, root-mean-square. 

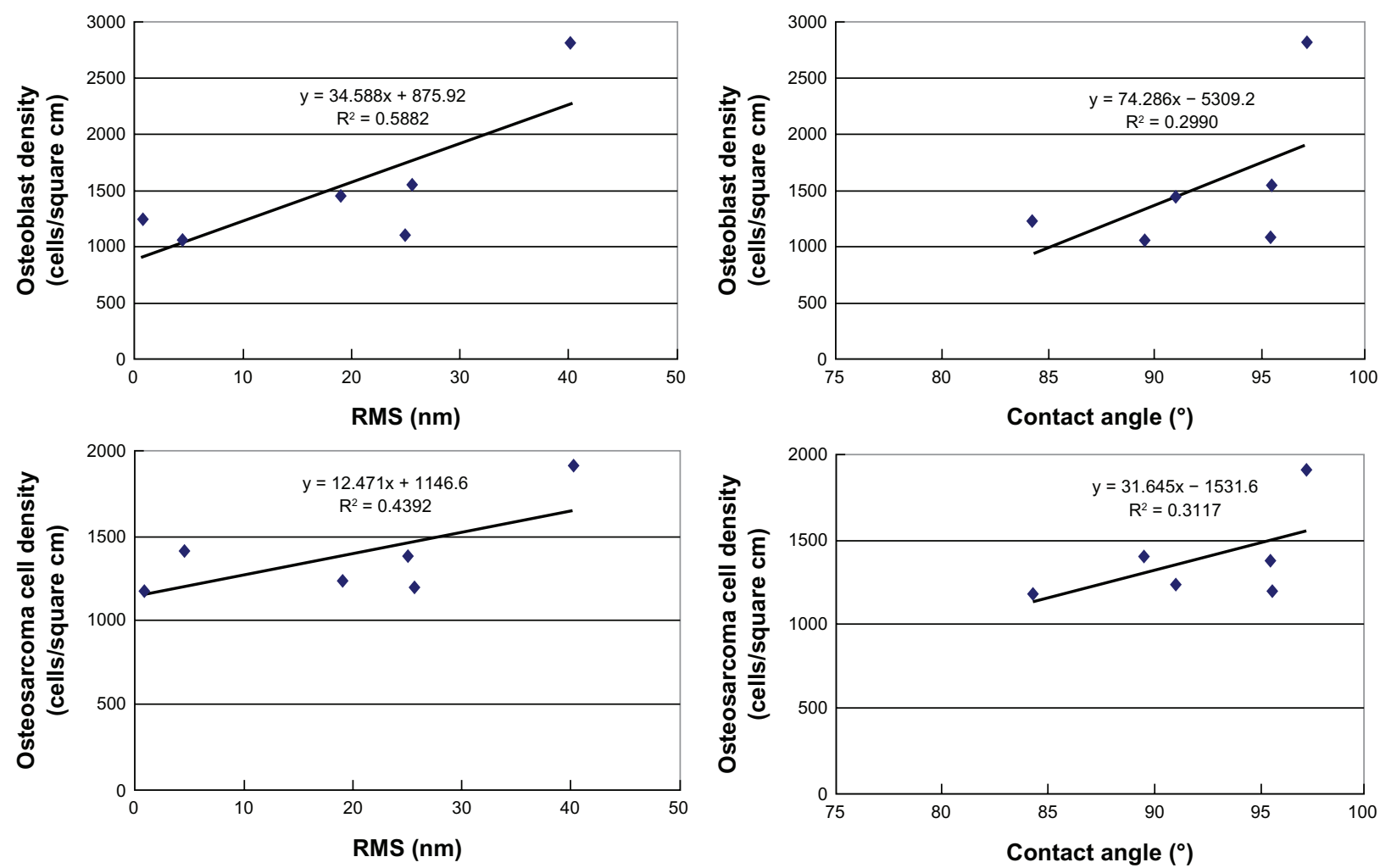

Figure 4 Correlation plots of healthy osteoblast density/RMS roughness values obtained from AFM, healthy osteoblast density/contact angle, osteosarcoma cell density/RMS roughness values obtained from AFM, and osteosarcoma cell density/contact angle. Abbreviations: AFM, atomic force microscopy; RMS, root-mean-square.

plots and associated $\mathrm{R}^{2}$ and R-values (Table 3; Figure 4), stronger correlations were found between either osteoblast or osteosarcoma cell density and the RMS roughness of the various PLGA nanopatterns than were found between either osteoblast or osteosarcoma cell density and the wettability of the various PLGA nanopatterns. These results indicate for the first time a higher degree of correlation between the ratio of healthy osteoblast density to osteosarcoma cell density on PLGA with altered nanoscale roughness than on PLGA with altered surface energy.

These results can be explained with respect to several things. First, higher RMS roughness values may equate to larger surface areas, and thus to more sites for the adsorption of the proteins that regulate cell adhesion. However, this does not explain why specifically $27 \mathrm{~nm}$ PLGA features were the best at increasing healthy to cancerous bone-cell density. Thus, it is important to mention that the RMS roughness value of the $27 \mathrm{~nm}$ PLGA nanopatterns was the closest to the roughness of the natural bone matrix. ${ }^{10}$ It has been speculated that cancerous bone has a different nanoscale roughness. In addition, $27 \mathrm{~nm}$ is the dimension closest to that of the endogenous proteins (such as vitronec- tin and fibronectin) that can adsorb to material surfaces to mediate cell adhesion; such nanoscale surface features may alter adsorbed protein bioactivity more easily than can smooth surface features. ${ }^{39,40}$ Clearly, future studies need to determine the exact mechanistic correlation between the PLGA nanopatterns on the responses of osteoblasts and osteosarcoma cells, and the reason for the observed difference between healthy osteoblast adhesion and osteosarcoma cell adhesion.

\section{Conclusion}

Using self-assembled polystyrene beads and PDMS molds as templates, an effective and inexpensive method of fabricating PLGA nanopatterns was developed in this study. Among the various PLGA surface features, the $27 \mathrm{~nm}$ PLGA nanopatterns showed a significant osteoblast density increase compared with the osteosarcoma cells. Upon further examination, a relatively strong correlation was found between either healthy osteoblast or osteosarcoma cell adhesion and the RMS roughness of PLGA surface features, thus indicating the importance of this surface-feature nanometer size for the design of better orthopedic anticancer medical devices. 


\section{Acknowledgment}

We would like to thank the Herman Foundation for their financial support and Dr Vera Fonseca and Professor Eric Darling for their technical support with the AFM.

\section{Disclosure}

The authors report no conflicts of interest in this work.

\section{References}

1. Lim JY, Donahue HJ. Cell sensing and response to micro- and nanostructured surfaces produced by chemical and topographic patterning. Tissue Eng. 2007;13:1879-1889.

2. Lord MS, Foss M, Besenbacher F. Influence of nanoscale surface topography on protein adsorption and cellular response. Nano Today. 2010;5:66-75.

3. Bettinger CJ, Langer R, Borenstein JT. Engineering substrate topography at the micro- and nanoscale to control cell function. Angew Chem Int Ed Engl. 2009; 48:5406-5412.

4. Gallagher JO, McGhee KF, Wilkinson CDW, Riehle MO. Interaction of animal cells with ordered nanotopography. IEEE Trans Nanobioscience. 2002;1(1):24-35.

5. Webster TJ, Ergun C, Doremus RH, Siegel RW, Bizios R. Specific proteins mediate enhanced osteoblast adhesion on nanophase ceramics. J Biomed Mater Res. 2000;51(3):475-484.

6. Smith LJ, Swaim JS, Yao C, Haberstroh KM, Nauman EA, Webster TJ. Increased osteoblast cell density on nanostructured PLGA-coated nanostructured titanium for orthopedic applications. Int $J$ Nanomedicine. 2007;2(3):493-501.

7. Karlsson M, Pålsgård E, Wilshaw PR, Di Silvio L. Initial in vitro interaction of osteoblasts with nano-porous alumina. Biomaterials 2003;24:3039-3048.

8. WebsterTJ, Ejiofor JU. Increased osteoblast adhesion on nanophase metals: Ti, Ti6Al4V, and CoCrMo. Biomaterials. 2004;25(19):4731-4739.

9. Dvir T, Timko BP, Kohane DS, Langer R. Nanotechnological strategies for engineering complex tissues. Nature Nanotechnology. 2011;6:13-21.

10. Liu H, Slamovich EB, Webster TJ. Increased osteoblast functions among nanophase titania/poly(lactide-co-glycolide) composites of the highest nanometer surface roughness. J Biomed Mater Res A. 2006; 78A(4):798-810

11. Ross AM, Jiang Z, Bastmeyer M, Lahann J. Physical aspects of cell culture substrates: topography, roughness, and elasticity. Small. 2012;8 336-345.

12. Zhong Y, Bellamkonda RV. Biomaterials for the central nervous system. $J R$ Soc Interface. 2008;5:957-966.

13. Dalby MJ, Gadegaard N, Tare R, et al. The control of human mesenchymal cell differentiation using nanoscale symmetry and disorder. Nature Materials. 2007;6:997-1005.

14. Thapa A, Miller DC, Webster TJ, Haberstroh KM. Nano-structured polymers enhance bladder smooth muscle cell function. Biomaterials 2003;24:2915-2922.

15. de Oliveira PT, Zalzal SF, Beloti MM, Rosa AL, Nanci A Enhancement of in vitro osteogenesis on titanium by chemically produced nanotopography. J Biomed Mater Res A. 2007;80(3): 554-563.

16. Lü J, Wang X, Marin-Muller C, et al. Current advances in research and clinical applications of PLGA-based nanotechnology. Expert Rev Mol Diagn. 2009;9(4):325-333.

17. Igwe J, Amini A, Mikael P, Laurencin C, Nukavarapu S. Part II: scaffolds for bone regeneration: nanostructured scaffolds for bone tissue engineering. In: Zilberman M, editor. Active Implants and Scaffolds for Tissue Regeneration. Berlin: Springer; 2011:168-192.
18. Makadia HK, Siegel SJ. Poly lactic-co-glycolic acid (PLGA) as biodegradable controlled drug delivery carrier. Polymers. 2011;3: $1377-1389$.

19. Dinarvand R, Sepehri N, Manoochehri S, Rouhani H, Atyabi F. Polylactide-co-glycolide nanoparticles for controlled delivery of anticancer agents. Int J Nanomedicine. 2011;6:877-885.

20. Betancourt T, Brannon-Peppas L. Micro- and nanofabrication methods in nanotechnological medical and pharmaceutical devices. Int $J$ Nanomedicine. 2006;1(4):483-489.

21. Norman JJ, Desai TA. Methods for fabrication of nanoscale topography for tissue engineering scaffolds. Ann Biomed Eng. 2006;34: 89-95.

22. Yang C, Huang L, Shen T, Yeh JA. Cell adhesion, morphology and biochemistry on nano-topographic oxidized silicon surfaces. Eur Cell Mater. 2010;20:415-430.

23. Miller DC, Haberstroh KM, Webster TJ. Mechanisms controlling increased vascular cell adhesion to nano-structured polymer films. Proceedings of the IEEE 30th Annual Northeastern Conference; 2004 Apr 17-18; Philadelphia, PA. New York: IEEE; 2004:120-128.

24. Comisar WA, Mooney DJ, Linderman JJ. Integrin organization: linking adhesion ligand nanopatterns with altered cell responses. JTheor Biol. 2011;274:120

25. Ayala R, Zhang C, Yang D, et al. Engineering the cell-material interface for controlling stem cell adhesion, migration, and differentiation. Biomaterials. 2011;32:3700-3711.

26. Ponche A, Bigerelle M, Anselme K. Relative influence of surface topography and surface chemistry on cell response to bone implant materials. Part 1: physico-chemical effects. Proc Inst Mech Eng $H$. 2010;224(12):1471-1479.

27. Ravichandran R, Liao S, Ng CC, Chan CK, Raghunath M, Ramakrishna S. Effects of nanotopography on stem cell phenotypes. World J Stem Cells. 2009;1(1):55-61.

28. Anselme K, Bigerelle M, Noel B, et al. Qualitative and quantitative study of human osteoblast adhesion on materials with various surface roughnesses. J Biomed Mater Res. 2000;49(2):155-163.

29. Brown XQ, Ookawa K, Wong JY. Evaluation of polydimethylsiloxane scaffolds with physiologically relevant elastic moduli: interplay of substrate mechanics and surface chemistry effects on vascular smooth muscle cell response. Biomaterials. 2005;26: $3123-3130$

30. Webster TJ, Schadler LS, Siegel RW, Bizios R. Mechanisms of enhanced osteoblast adhesion on nanophase alumina involve vitronectin. Tissue Eng. 2001;7(3):291-299.

31. Yao C, Perla V, McKenzie JL, Slamovich EB, Webster TJ. Anodized Ti and Ti6Al4V possessing nanometer surface features enhances osteoblast adhesion. J Biomed Nanotechnol. 2005;1(1):68-75.

32. Malawer MM, Helman LJ, O'Sullivan B. Sarcomas of bone. In: DeVita VT, Hellman S, Rosenberg SA, editors. Cancer: Principles and Practice of Oncology. 7th ed. Philadelphia: Lippincott Williams \& Wilkins; 2004.

33. Tran P, Webster TJ. Enhanced osteoblast adhesion on nanostructured selenium compacts for anti-cancer orthopedic applications. Int $J$ Nanomedicine. 2008;3(3):391-399.

34. Hu Q, Cai Y, Shi Z, Yan W, Tang R. Inhibition of proliferation of osteosarcoma by nano calcium phosphates: potential hard tissue repair after tumor extraction. Front Mater Sci China. 2007;1(1):30-38.

35. Shi Z, Huang X, Liu B, Tao H, Cai Y, Tang R. Biological response of osteosarcoma cells to size-controlled nanostructured hydroxyapatite. J Biomater Appl. 2010;25(1):19-27.

36. Zhang L, Chun YW, Webster TJ. Decreased lung carcinoma cell density on select polymer nanometer surface features for lung replacement therapies. Int J Nanomedicine. 2010;5:269-279.

37. Zhang L, Webster TJ. Decreased lung carcinoma cell functions on select polymer nanometer surface features. $J$ Biomed Mater Res A. 2012;100A:94-102. 
38. Zhang L, Webster TJ. Decreased breast adenocarcinoma cell functions on select polymer nanometer surface features. Bioengineering Conference (NEBEC), 2011 IEEE 37th Annual Northeast. Obeid I, editor. Washington, DC: IEEE; 2011:1-2.
39. Elias KL, Price RL, Webster TJ. Enhanced functions of osteoblasts on nanometer diameter carbon fibers. Biomaterials. 2002;23:3279-3385.

40. Koteliansky VE, Glukhova MA, Bejanian MV, et al. A study of the structure of fibronectin. Eur J Biochem. 1981;119:619-629.

\section{Publish your work in this journal}

The International Journal of Nanomedicine is an international, peerreviewed journal focusing on the application of nanotechnology in diagnostics, therapeutics, and drug delivery systems throughout the biomedical field. This journal is indexed on PubMed Central, MedLine, CAS, SciSearch $\AA$, Current Contents ${ }^{\circledR} /$ Clinical Medicine,
Journal Citation Reports/Science Edition, EMBase, Scopus and the Elsevier Bibliographic databases. The manuscript management system is completely online and includes a very quick and fair peer-review system, which is all easy to use. Visit http://www.dovepress.com/ testimonials.php to read real quotes from published authors. 